\title{
Economic impact of biomaterials for bone regeneration in Brazil during the
}

\section{pandemic}

\author{
Impacto econômico de biomateriais para regeneração óssea no Brasil durante a pandemia \\ Impacto económico de los biomateriales para la regeneración ósea en Brasil durante la pandemia
}

Received: 11/14/2021 | Reviewed: 11/20/2021 | Accept: 11/24/2021| Published: 12/07/2021

\author{
Lana Karine Araújo \\ ORCID: https://orcid.org/0000-0003-2200-8313 \\ Universidade Federal do Ceará, Brasil \\ E-mail: lanakarine1380@gmail.com \\ Jacques Antonio Cavalcante Maciel \\ ORCID: https://orcid.org/0000-0002-2293-8433 \\ Universidade Federal do Ceará, Brasil \\ E-mail: jacques.maciel@sobral.ufc.br \\ Marcelo Miranda de Melo \\ ORCID: https://orcid.org/0000-0003-2605-1319 \\ Universidade Federal do Ceará, Brasil \\ E-mail: marcelomirandamelo3m@gmail.com \\ Igor Iuco Castro-Silva \\ ORCID: https://orcid.org/0000-0003-4815-6357 \\ Universidade Federal do Ceará, Brasil \\ E-mail: igor.iuco@sobral.ufc.br
}

\begin{abstract}
Implantable devices are therapeutic options for oral rehabilitation, with several presentations available in the dental consumption market. The consumption power of health products is a little explored in the literature, particularly in the face of financial crises. The aim of this study was to evaluate the economic impact of biomaterials for bone regeneration in Brazil during the pandemic. A quantitative study was carried out through online document analysis, with publicly accessible secondary data extracted from IBGE and websites for the sale of dental products. Data collection in the second quarter of 2020 and 2021 of absolute values of products, official GDP data and population estimates allowed the generation of a biomaterial/income coefficient. The categories obtained from grafts and membranes were stratified by composition, origin and industry. Statistical analysis used the Shapiro-Wilk test to assess normality, the non-parametric Kruskall-Wallis test to compare the means of variables and the Wilcoxon test for paired samples of medians according to the two periods, considering significant differences if $p<0.05$. Of 97 products analyzed, a higher frequency of bone grafts than barrier membranes was observed, with an average growth of $18.5 \%$ in the price of biomaterials, below $28.7 \%$ of GDP in the same period. The highest prevalence of biomaterials was the ceramic composition for bone grafts and resorbable polymeric for membranes, from the xenogenous source and Brazilian industry. There was a chronological decrease in the biomaterial/income coefficient in most categories, with a drop in the general average from $4.67 \pm 4.40 \%$ to $4.30 \pm 3.96 \%$, accompanied by an increase in the median, demonstrating a trend towards homogeneity of this coefficient in the comparison between years. The drop in the coefficient indicates a greater purchasing power of biomaterials by the potential consumer. Market knowledge can contribute for the decision making in clinical planning involving bone regeneration.
\end{abstract}

Keywords: Costs and cost analysis; Bone regeneration; Biocompatible materials; Dentistry.

\section{Resumo}

Dispositivos implantáveis constituem opções terapêuticas para a reabilitação bucal, com diversas apresentações disponíveis no mercado de consumo odontológico. O poder de consumo de produtos em saúde é pouco explorado na literatura, em especial diante de crises financeiras. O objetivo deste estudo foi avaliar o impacto econômico de biomateriais para regeneração óssea no Brasil durante a pandemia. Foi realizado um estudo quantitativo por análise documental on-line, com dados secundários de acesso público extraídos do IBGE e de sites de venda de produtos odontológicos. A coleta no segundo trimestre de 2020 e 2021 de valores absolutos dos produtos, dados oficiais de PIB e estimativa populacional, permitiu a geração de um coeficiente biomaterial/renda. As categorias obtidas de enxertos e membranas foram estratificadas em composição, origem e indústria. A análise estatística usou teste de Shapiro-Wilk para avaliar a normalidade, o teste não-paramétrico de Kruskall-Wallis para comparação entre as médias das variáveis e o teste de Wilcoxon para amostras pareadas de medianas conforme os dois períodos, considerando diferenças significativas se $\mathrm{p}<0,05$. De 97 produtos analisados, foi observada maior frequência de enxertos ósseos do que membranas de barreira, com um crescimento médio de $18,5 \%$ no preço de biomateriais, abaixo de $28,7 \%$ do PIB no 
mesmo período. A maior prevalência de biomateriais foi da composição cerâmica para enxertos ósseos e polimérica reabsorvível para membranas, da fonte xenógena e da indústria brasileira. Houve diminuição cronológica do

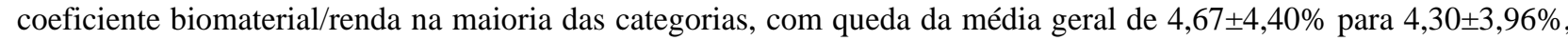
acompanhada do aumento da mediana, demonstrando tendência a homogeneidade deste coeficiente na comparação entre anos. A queda do coeficiente indica um maior poder de compra dos biomateriais pelo potencial consumidor. $\mathrm{O}$ conhecimento do mercado pode contribuir para a tomada de decisão no planejamento clínico envolvendo regeneração óssea.

Palavras-chave: Custos e análise de custo; Regeneração óssea; Materiais biocompatíveis; Odontologia.

\section{Resumen}

Los dispositivos implantables son opciones terapéuticas para la rehabilitación oral, con varias presentaciones disponibles en el mercado de consumo dental. El poder de consumo de los productos para la salud está poco explorado en la literatura, especialmente frente a crisis financieras. El objetivo de este estudio fue evaluar el impacto económico de los biomateriales para la regeneración ósea en Brasil durante la pandemia. Se realizó un estudio cuantitativo mediante análisis de documentos en línea, con datos secundarios de acceso público extraídos del IBGE y de sitios web para la venta de productos dentales. La recopilación en el segundo trimestre de 2020 y 2021 de valores absolutos de productos, datos oficiales del PIB y estimaciones de población permitió generar una relación biomaterial/ingreso. Las categorías obtenidas de injertos y membranas se estratificaron por composición, origen e industria. El análisis estadístico utilizó la prueba de Shapiro-Wilk para evaluar la normalidad, la prueba no paramétrica de Kruskall-Wallis para comparar las medias de las variables y la prueba de Wilcoxon para muestras apareadas de medianas según los dos períodos, considerando diferencias significativas si p <0.05. De los 97 productos analizados, se observó una mayor frecuencia de injertos óseos que membranas de barrera, con un crecimiento promedio del 18,5\% en el precio de los biomateriales, por debajo del 28,7\% del PIB en el mismo período. La mayor prevalencia de biomateriales fue la composición cerámica para injertos óseos y polímero reabsorbible para membranas, de la fuente xenógena y industria brasileña. Hubo una disminución cronológica en el coeficiente biomaterial/ingreso en la mayoría de las categorías, con una caída en el promedio general de $4.67 \pm 4.40 \%$ a $4.30 \pm$ $3.96 \%$, acompañado de un aumento en la mediana, lo que demuestra una tendencia hacia la homogeneidad de este coeficiente en la comparación entre años. La caída del coeficiente indica un mayor poder adquisitivo de biomateriales por parte del consumidor potencial. El conocimiento del mercado puede contribuir a la toma de decisiones en la planificación clínica que involucre la regeneración ósea.

Palabras clave: Costos y análisis de costo; Regeneración ósea; Biomateriales biocompatibles; Odontología.

\section{Introduction}

A large multifactorial demand for orofacial bone losses, derived from traumatic etiologies, congenital malformations, neoplasms and other disorders of teeth and support structures, have clinical or hospital treatment through regenerative biomaterials (Castro-Silva, Lima \& Granjeiro, 2013). Implantable devices to assist in the morphofunctional repair of lost bone have been the subject of more accentuated scientific research since the 1980s and nowadays set the era of smart biomaterials by greater understanding and modulation of their interaction with hard tissues bio-environment (Castro-Silva et al., 2021; Montoya et al., 2021).

Biomaterials used in guided bone regeneration (GBR) include bone grafts and barrier membranes, which may vary in origin (autogenous, allogeneic, xenogeneic or alloplastic), composition (metals, ceramics, bioglasses, polymers or composites), interaction with biological environment (bioinert, bioactive, biodegradable and/or biomimetic) and ways of manufacturing (from conventional physical-chemical treatments to the latest use of bio-based sustainable raw materials and 3D biofabrication) (Araújo et al., 2021; Araújo et al., 2020; Costa, 2019; Aguilar, Twardowski \& Wohlgemuth, 2019). These biomaterials can be used in combination, enabling a synergistic effect to increase bone neoformation (Castro-Silva \& Coutinho, 2012). Despite its great heterogeneity of presentations and uses, there is no ideal biomaterial for bone regeneration that primarily meets all of the above requirements, which drives the constant biotechnological development (Matichescu et al., 2020; Haugen et al., 2019).

International indicators show that global growth projections in the last decade for biomaterials market vary between $0.93 \%$ and $0.95 \%$ per year until 2027 (Maximize Market Research, 2021). Europe ruled the worldwide market, followed by North America, Asia Pacific, Middle East \& Africa and South America (Maximize Market Research, 2021). Brazil leads the consumption of biomaterials in Latin and Central America, followed by Argentina and Mexico, and presents the 
orthopedic/dental segment as the second most promising, only behind cardiovascular devices, with an overall expected growth in the last decade of $1.53 \%$ per year until 2028, where it is hoped to achieve USD 8.66 Billion (Zion Market Research, 2021). Despite the high consumer market, North America region held a substantial share of the Brazil biomaterials market in 2020, showing the strong dependence of foreign industry (Zion Market Research, 2021).

Growth in the dental consumables market can primarily be attributed to the rising incidence of dental diseases, increasing demand for cosmetic dentistry, growing dental tourism in emerging markets, and the increasing disposable income in developing countries (Zion Market Research, 2021). In developed countries, the treatment of oral diseases including dental biomaterials was responsible for 5\% of the overall health expenditure (Persistence Market Research, 2021). EU Member States costs ranged from $€ 72$ in England (if treated within the NHS) to $€ 603$ in Denmark (Eaton et al., 2019). On the other hand, irrespective of age, income level, and type of insurance, more north american people reported financial barriers to receiving dental care, compared to any other type of health care (Vujicic, Buchmueller \& Klein, 2017).

According to IBGE (2021), Brazil spends $8 \%$ of its gross domestic product (GDP) on health, with a little more than half on private spending. Over the last 3 decades in Brazil, health expenditure per capita has ranged from USD 535.10 to USD 984.90, with private spending slightly higher than public spending, despite of dental centers in the Unified Health System are responsible for the 13\% increase in population coverage between 1998 and 2013 (Castro et al., 2019). The number of dental surgeons in Brazil is high, although they are lower in the public sector compared to the private sector and this may imply barriers to dental care access in Brazil (Cascaes, Dotto \& Bomfim, 2018). Cacaes et al. (2018) highlighted that only $2.5 \%$ of Brazilian households have reported spending on private dental insurance, having association of higher spending with sociodemographic profile, including higher educational level, income and Southeast Region.

The COVID-19 pandemic caused deep variation of quartely GDP in Brazil between second quarter of 2020 (-9\%) and second quarter of $2021(-0.1 \%)$, with a year-on-year growth of $12.4 \%$, the highest quarterly rate of the entire historical series of GDP since 1996 (Alvarenga \& Silveira, 2021). In this comparison, there was an improvement in the rate of exports (from $0.5 \%$ to $9.4 \%$ ), services (from -8.7 to $0.7 \%$ ), industry (from -12.1 to $-0.2 \%$ ), imports (from $-10 \%$ to $-0.6 \%$ ) and household consumption (from $-11.3 \%$ to $0 \%$ ), accompanied by a decline in agriculture (from $0.4 \%$ to $-2.8 \%$ ), conditions that would help to understand the future dynamics of the post-pandemic market (Alvarenga \& Silveira, 2021).

Recent publications demonstrate that the negative impact of initial phase of the pandemic on general trade due to restrictions imposed by lockdown also applied to the GBR biomaterials market, although the analysis of its consequences is still incipient (Maximize Market Research, 2021; Zion Market Research, 2021). Despite much debate about biological benefits of GBR biomaterials, it is possible to observe the scarcity of studies that address the economic aspects of this segment (Araújo et al., 2020; Castro-Silva et al, 2013). In hypothesis, the purchasing power of GBR biomaterials in Brazil could also have fluctuated according to a period of financial crisis. To fill this knowledge gap, the aim of this study was to evaluate the economic impact of biomaterials for bone regeneration in Brazil during the pandemic.

\section{Material and Methods}

The study followed a case study typology, based on online document analysis, delineated from the market and population context in Brazil. According to Pereira, Shitsuka, Parreira and Shitsika (2018), a case study consists of a description and analysis, as detailed as possible, of a condition that presents some particularity that makes it special and contributes to scientific knowledge. It is an empirical investigation of a contemporary phenomenon within its real-life context, with a tendency to try to clarify decisions (Yin, 2015). This case study was carried out in accordance with the international STROBE guidelines on reporting observacional studies (Malta et al., 2010). 
Within the ethical-legal aspects, the research was in accordance with the Resolution n. 510/2016 of the National Health Council in Brazil for surveys considering the use of publicly accessible secondary data.

In June 2020 and 2021, information about commercial bone grafts and membrane barriers for bone regeneration in dental applications were accessed in different resellers, following the reference of Araújo et al. (2021). Data collection was performed on the websites of the following companies: DentalCremer, PromoDental, Pharmadent, Domedica, SuryaDental, DentalFerraz, Central do implante, CDDental, Magalu and MercadoLivre. The average absolute market price for each product was recorded, considering each period mentioned. To draw a simplified economic comparison, the value of each biomaterial against the purchasing power or income of the population was considered. In this context, public access sociodemographic data published in Brazil, gross domestic product/GDP in the temporal variables of the second quarter of 2020 and the second quarter of 2021 ( $R \$ 1,653$ billion and $R \$ 2,143.4$ billion, respectively) and of the population estimate released in July of each year (211,755,692 and 213,317,639 individuals, respectively) (IBGE, 2021). To design this relationship, the following equation was constructed:

$$
C=[P B /(G D P x / P E x)] * 100
$$

Where: $\mathrm{C}=$ biomaterial/income coefficient, $\mathrm{PB}=$ price of biomaterial in reals $(\mathrm{R} \$), \mathrm{GDP}=$ quarterly gross domestic product in reals $(\mathrm{R} \$), \mathrm{PE}=$ population estimate, $\mathrm{x}=$ second quarter of 2020 or 2021. Relative value obtained with the equation was expressed as a percentage for each product analyzed. This index would indicate a relative or percentage forecast of the consumer's quarterly income commitment with a potential spend on GBR biomaterial.

For a descriptive data analysis, the mean of the coefficients obtained for each period were presented into three stratifications: composition (ceramic or other implants, including bioglass, polymers or composites), origin (xenogeneic or alloplastic implants, excluding autografts and allografts due to non-commercialization) and industry (Brazilian or foreign).

Comparison within the proposed stratifications used Shapiro-Wilk test and in most variables, there was no normal distribution of data. The non-parametric Kruskall-Wallis test was then applied to identify whether there was a statistical difference between the means. To validate the comparison of the distribution of the biomaterial/income coefficient between the periods, the Shapiro-Wilk test was used, considering the lack of normality of the data presented, and the median was adopted for subsequent analysis of paired samples by the Wilcoxon test. Significant differences were considered if $\mathrm{P}<0.05$.

\section{Results}

The sample obtained from commercial dental products for bone regeneration purposes was 97 biomaterials. Table 1 provides information on all products recovered in the period consulted, including bone grafts and barrier membranes in its various commercial presentations, including formats, weights, volumes and granulometries. There was a higher frequency of bone grafts ( $n=62$ or $64 \%$ of the total), which reached almost twice as many barrier membranes ( $n=35$ or $36 \%$ of the total). 
Table 1 - Commercial dental products for guided bone regeneration available in Brazilian market.

\begin{tabular}{|c|c|}
\hline \multicolumn{2}{|c|}{ Bone grafts } \\
\hline Alobone ${ }^{\circledR} 0.5 \mathrm{~g}$, dense granules (Osseocom) & Bonefill@ Porous $0.5 \mathrm{~g}$, thick granules (Bionnovation) \\
\hline Alobone $® 0.5 \mathrm{~g}$, porous granules (Osseocom) & Bonefill ${ }^{\circledR}$ Porous 1g, fine granules (Bionnovation) \\
\hline Bio-Gen ${ }^{\circledR}$ cortical $0.5 \mathrm{~g}, 0.5-1 \mathrm{~mm}$ granules (Bioteck) & Bonefill ${ }^{\circledR}$ Porous 1g, medium granules (Bionnovation) \\
\hline Bio-Gen® mix $0.25 \mathrm{~g}, 0.5-1 \mathrm{~mm}$ granules (Bioteck) & Bonefill@ Porous 1g, thick granules (Bionnovation) \\
\hline Bio-Gen ${ }^{\circ} \operatorname{mix} 0.5 \mathrm{~g}, 0.5-1 \mathrm{~mm}$ granules (Bioteck) & COL-HAP-91@ 1g, $\pm 0.841 \mathrm{~mm}$ medium granules $(\mathrm{JHS})$ \\
\hline Bio-Gen ${ }^{\circledR} 0.5 \mathrm{~cm}^{3}$ putty (Bioteck) & Extragraft XG-13® $0.5 \mathrm{~g}$ block (Silvestre Labs) \\
\hline Bio-Gen ${ }^{\circledR}$ spongy, $2 \mathrm{~cm}^{3}$ putty (Bioteck) & Extragraft XG-13® 1g block (Silvestre Labs) \\
\hline Bio-Gen ${ }^{\circledR}$ spongy $0.5 \mathrm{~g}, 0.25-1 \mathrm{~mm}$ granules (Bioteck) & GenMix ${ }^{\circledR} 0.5 \mathrm{~g}, 0.25-1 \mathrm{~mm}$ granules (Baumer) \\
\hline Bio-Gen® spongy $0.5 \mathrm{~g}, 1-2 \mathrm{~mm}$ granules (Bioteck) & GenMix ${ }^{\circledR} 1 \mathrm{~g}, 0.25-1 \mathrm{~mm}$ granules (Baumer) \\
\hline Bio-Gen $\circledast$ spongy $1 \mathrm{~g}, 2-3 \mathrm{~mm}$ granules (Bioteck) & GenOx® inorganic, $0.5 \mathrm{~cm}^{3}$ granules (Baumer) \\
\hline Bio-Graft $₫$ spongy, $0.5 \mathrm{~cm}^{3}$ screwable block (Geistlich) & GenOx ${ }^{\circledR}$ inorganic, $1 \mathrm{~cm}^{3}$ granules (Baumer) \\
\hline Bio-Oss Collagen ${ }^{\circledR} 0.1 \mathrm{~g}$ block (Geistlich) & GenOx ${ }^{\circledR}$ organic, $0.5 \mathrm{~cm}^{3}$ porous matrix (Baumer) \\
\hline Bio-Oss Collagen $® 0.25 \mathrm{~g}$ block (Geistlich) & GenOx® organic, $1 \mathrm{~cm}^{3}$ porous matrix (Baumer) \\
\hline Bio-Oss Collagen $® 0.5 \mathrm{~g}$ block (Geistlich) & GenPhos $® 0.7 \mathrm{~g}, 0.5-0.75 \mathrm{~mm}$ granules (Baumer) \\
\hline Bio-Oss® $0.25 \mathrm{~g}, 0.25-1 \mathrm{~mm}$ small granules (Geistlich) & Lumina Bone $® 0.5 \mathrm{~g}$, fine granules (Critéria) \\
\hline Bio-Oss ${ }^{\circledR} 0.5 \mathrm{~g}, 0.25-1 \mathrm{~mm}$ small granules (Geistlich) & Lumina Bone ${ }^{\circledR} 0.5 \mathrm{~g}$, medium granules (Critéria) \\
\hline Bio-Oss® 1g, 0.25-1mm small granules (Geistlich) & Lumina Bone ${ }^{\circledR} 0.5 \mathrm{~g}$, thick granules (Critéria) \\
\hline Bio-Oss $® 2 \mathrm{~g}, 0.25-1 \mathrm{~mm}$ small granules (Geistlich) & Lumina Bone ${ }^{\circledR}$ Porous 0.5g, fine granules (Critéria) \\
\hline Bio-Oss ${ }^{\circledR} 0.5 \mathrm{~g}, 1-2 \mathrm{~mm}$ large granules (Geistlich) & Lumina Bone $®$ Porous $0.5 \mathrm{~g}$, thick granules (Critéria) \\
\hline Bio-Oss ${ }^{\circledR} 1 \mathrm{~g}, 1-2 \mathrm{~mm}$ large granules (Geistlich) & Nanosynt ${ }^{\circledR} 0.5 \mathrm{~g}, 0.2-0.5 \mathrm{~mm}$ granules $(\mathrm{FGM})$ \\
\hline Bio-Oss ${ } 2 \mathrm{~g}, 1-2 \mathrm{~mm}$ large granules (Geistlich) & Nanosynt ${ }^{\circledR} 0.5 \mathrm{~g}, 0.5-1 \mathrm{~mm}$ granules (FGM) \\
\hline Bio-Oss ${ }^{\circledR}$ spongy, $2 \mathrm{~cm}^{3}$ block (Geistlich) & Nanosynt $\AA 1 \mathrm{~g}, 0.2-0.5 \mathrm{~mm}$ granules $(\mathrm{FGM})$ \\
\hline Bio-Oss ${ }^{\circledR}$ pen $0.25 \mathrm{~g}, 0.25-1 \mathrm{~mm}$ small granules (Geistlich) & Nanosynt ${ }^{\circledR} 1 \mathrm{~g}, 0.5-1 \mathrm{~mm}$ granules $(\mathrm{FGM})$ \\
\hline Bio-Oss ${ }^{\circledR}$ pen $0.5 \mathrm{~g}, 0.25-1 \mathrm{~mm}$ small granules (Geistlich) & Osteogen ${ }^{\circ} 0.3 \mathrm{~g}, 0.3-0.4 \mathrm{~mm}$ granules (Intra-Lock) \\
\hline Bio-Oss $®$ pen $0.5 \mathrm{~g}, 1-2 \mathrm{~mm}$ small granules (Geistlich) & Osteogen ${ } 0.4 \mathrm{~g}, 0.3-0.4 \mathrm{~mm}$ granules (Intra-Lock) \\
\hline BoneCeramic $® 0.5 \mathrm{~g}, 0.5-1 \mathrm{~mm}$ granules (Straumann) & 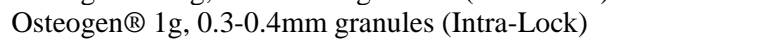 \\
\hline Bonecol ${ }^{\circledR} 10 \times 20 x 0.3 \mathrm{~mm}$ strip (Neomatrix) & OrthoGen ${ }^{\circledR} 5 \times 15 \times 15 \mathrm{~cm}^{3}$ block (Baumer) \\
\hline Bonefill@ 5x10x10mm block (Bionnovation) & OrthoGen ${ }^{\circledR} 0.5 \mathrm{~cm}^{3}, 0.25 \times 0.5 \mathrm{~mm}$ granules (Baumer) \\
\hline Bonefill@ $5 \times 20 \times 20 \mathrm{~mm}$ block (Bionnovation) & OrthoGen ${ }^{\circledR} 0.5 \mathrm{~cm}^{3}, 0.5 \times 0.75 \mathrm{~mm}$ granules (Baumer) \\
\hline Bonefill $®$ porous $0.5 \mathrm{~g}$, fine granules (Bionnovation) & Osseoplus $₫ \pm 0.841 \mathrm{~mm}$ medium granules $(\mathrm{JHS})$ \\
\hline Bonefill $®$ porous $0.5 \mathrm{~g}$, medium granules (Bionnovation) & Synthetic bone graft $0.5 \mathrm{~g}, 0.5-0.6 \mathrm{~mm}$ granules (Bionnovation) \\
\hline \multicolumn{2}{|c|}{ Barrier membranes } \\
\hline Allumina Standard® membrane $3 \times 2.5 \mathrm{~mm}$ (BiomacMed) & Lumina Grid® membrane 2x3x0.08cm (Critéria) \\
\hline Biocollagen $®$ membrane $2.5 \times 2.5 \times 0.02 \mathrm{~cm}$ (Bioteck) & Lumina PTFE® membrane 2x3x0.1cm (Critéria) \\
\hline Biocollagen ${ }^{\circledR}$ membrane $1.5 \times 2 \times 0.02 \mathrm{~cm}$ (Bioteck) & Lyostyp ${ }^{\circledR}$ membrane $0.3 \times 0.5 \mathrm{~cm}$ (Braun) \\
\hline Bio-Gide $®$ membrane $3.2 \mathrm{~cm}^{2}$ (Geistlich) & Lyostyp ${ }^{\circledR}$ membrane $2 \times 3 \mathrm{~cm}$ (Braun) \\
\hline Bio-Gide $\AA$ compressed membrane $3.3 \mathrm{~cm}^{2}$ (Geistlich) & Pratix® membrane $15 \times 25 \mathrm{~cm}$ (Baumer) \\
\hline Bio-Gide $®$ membrane $3.5 \mathrm{~cm}^{2}$ (Geistlich) & Pratix $®$ membrane $30 x 40 \mathrm{~cm}$ (Baumer) \\
\hline Bio-Gide $₫$ membrane $6 \mathrm{~cm}^{2}$ (Geistlich) & Surgidry ${ }^{\circledR}$ sponge $2 \times 2 \times 0.3 \mathrm{~mm}$ (Technodry) \\
\hline Bio-Gide $₫$ membrane $6.3 \mathrm{~cm}^{2}$ (Geistlich) & Surgidry ${ }^{\circledR}$ film $2 \times 2 \mathrm{~mm}$ (Technodry) \\
\hline Bio-Gide $®$ membrane $12 \mathrm{~cm}^{2}$ (Geistlich) & Surgitime ${ }^{\circledR}$ PTFE membrane $3 \times 2 \times 0.01 \mathrm{~cm}$ (Bionnovation) \\
\hline Bio-Gide $®$ membrane $14 \times 2 \times 4 \mathrm{~cm}$ (Geistlich) & Surgitime $®$ PTFE membrane $3 \times 2 \times 0.025 \mathrm{~cm}$ (Bionnovation) \\
\hline Bone Heal ${ }^{\circledR}$ membrane $3 \times 4 \mathrm{~cm}$ (Bone Heal) & Surgitime $®$ Seal Ti membrane $3.4 \times 2.5 \times 0.04 \mathrm{~cm}$ (Bionnovation) \\
\hline GenDerm ${ }^{\circledR}$ membrane $2 \times 2 \mathrm{~cm}$ (Baumer) & Surgitime ${ }^{\circledR}$ Ti membrane $2.5 \times 0.04 \times 0.015 \mathrm{~cm}$ (Bionnovation) \\
\hline GenDerm $\AA$ membrane $3 \times 3 \mathrm{~cm}$ (Baumer) & Techgraf ${ }^{\circledR}$ membrane $2 \times 2 \mathrm{~cm}$ (Baumer) \\
\hline GenDerm $®$ Flex membrane $2 \times 2 \mathrm{~cm}$ (Baumer) & Techgraf ${ }^{\circledR}$ membrane $2 \times 3 \mathrm{~cm}$ (Baumer) \\
\hline GrenMembrane $®$ membrane $4 \times 2.5 \times 0.01 \mathrm{~cm}$ (Regener) & Techgraf ${ }^{\circledR}$ membrane $3 \times 3 \mathrm{~cm}$ (Baumer) \\
\hline GrenMembrane ${ }^{\circledR}$ membrane $4 \times 2.5 \times 0.02 \mathrm{~cm}$ (Regener) & Ti Mesh $®$ membrane $1.8 \times 2.5 \times 0.15 \mathrm{~cm}$ (Intra Lock) \\
\hline Lumina Coat ${ }^{\circledR}$ membrane $2 \times 3 \times 0.1 \mathrm{~cm}$ (Critéria) & Titânio INP® membrane $2.5 \times 2 \times 0.08 \mathrm{~cm}$ (INP) \\
\hline Lumina Coat ${ }^{\circledR}$ double time membrane $2 \times 3 \times 0.2 \mathrm{~cm}$ (Critér & \\
\hline
\end{tabular}

Source: Elaborated by the authors (2021).

When comparing the average of the absolute values of the two categories in the second quarters of 2020 and 2021 , grafts had a $20.3 \%$ increase in price (from $\mathrm{R} \$ 374.36$ to $\mathrm{R} \$ 450.37$ ), while membranes had an increase of $15 \%$ in the price (from $\mathrm{R} \$ 346.55$ to $\mathrm{R} \$ 398.62)$. When considering all biomaterials, including grafts and membranes, there was an $18.5 \%$ increase in the overall price (from $\mathrm{R} \$ 364.33$ to $\mathrm{R} \$ 431.70$ ).

Considering only the income of Brazilian citizens, the general purchasing power increased in the comparison between the second quarter of 2020 and 2021 (from $\mathrm{R} \$ 7,806.17$ to $\mathrm{R} \$ 10,047.93$, respectively), which is equivalent to an increase of $28.7 \%$, above of the rate found for GBR biomaterials.

According to the composition, there was a high prevalence of ceramic grafts (48 or $77.4 \%$ of this total) compared to other types of grafts ( 14 or $22.6 \%$ of this total), while most membranes exhibited a resorbable polymeric pattern $(26$ or $74.3 \%$ 
of this total) compared to non-resorbable membranes of multiple compositions ( 9 or $25.7 \%$ of this total). There was a small decrease in the biomaterial/income coefficient from the second quarter of 2020 to the second quarter of 2021 in all analyzed subgroups, with statistical difference $(\mathrm{P}<0.05)$. Figure 1 illustrates the temporal analysis of biomaterial/income coefficient according to composition.

Figure 1 - Temporal analysis of biomaterial/income coefficient according to composition.
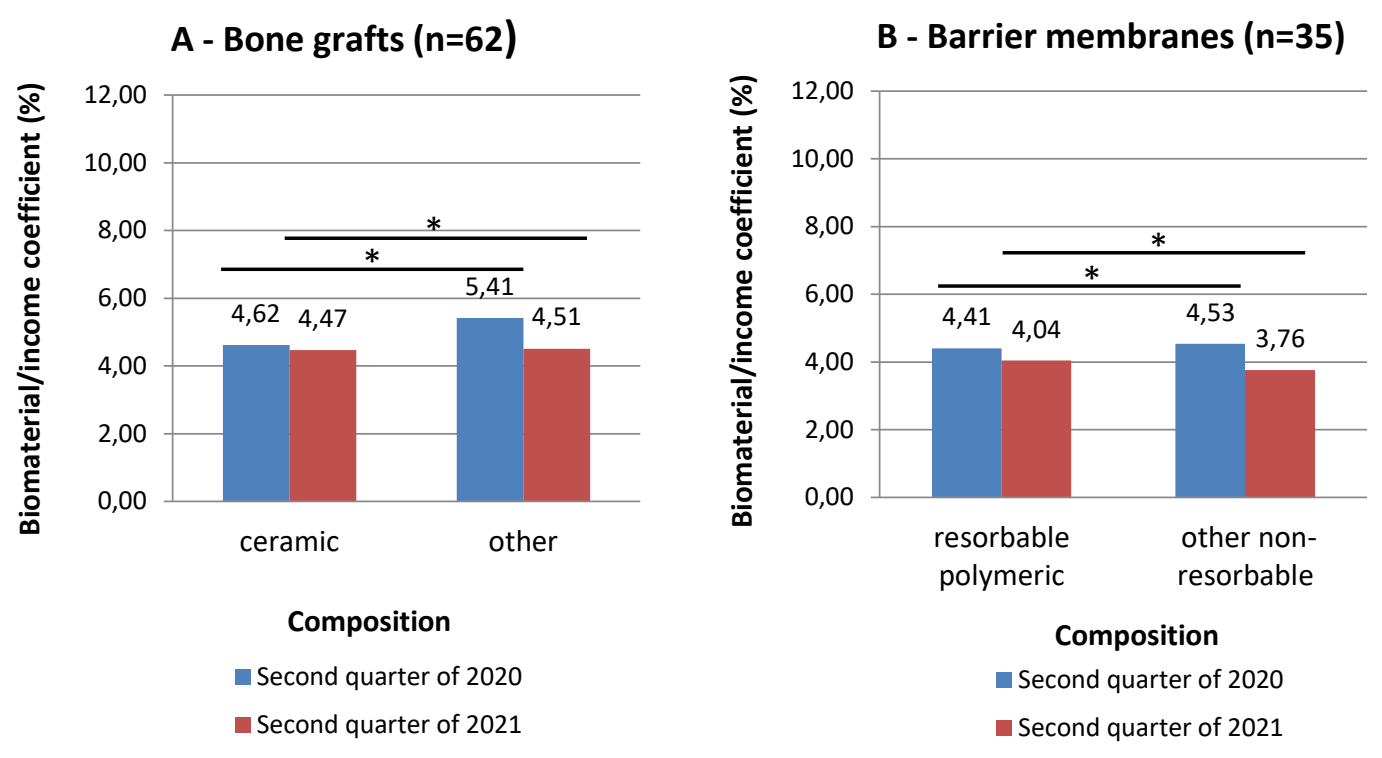

$* \mathrm{P}<0.05$. Source: Elaborated by the authors (2021).

According to the source, there was a high prevalence of xenogeneic grafts (48 or $77.4 \%$ of this total) compared to alloplastics ( 14 or $22.6 \%$ of this total), while xenogeneic membranes (20 or $57.1 \%$ of this total) exhibited a frequency closer to that of alloplastics (15 or $42.9 \%$ of this total). The coefficient of bone xenografts proved to be higher than that of alloplastic grafts in all periods. There was a small decrease in the biomaterial/income coefficient from the second quarter of 2020 to the second quarter of 2021 in all analyzed subgroups, with statistical difference $(\mathrm{P}<0.05)$. Figure 2 illustrates the temporal analysis of biomaterial/income coefficient according to source. 
Figure 2 - Temporal analysis of biomaterial/income coefficient according to source.
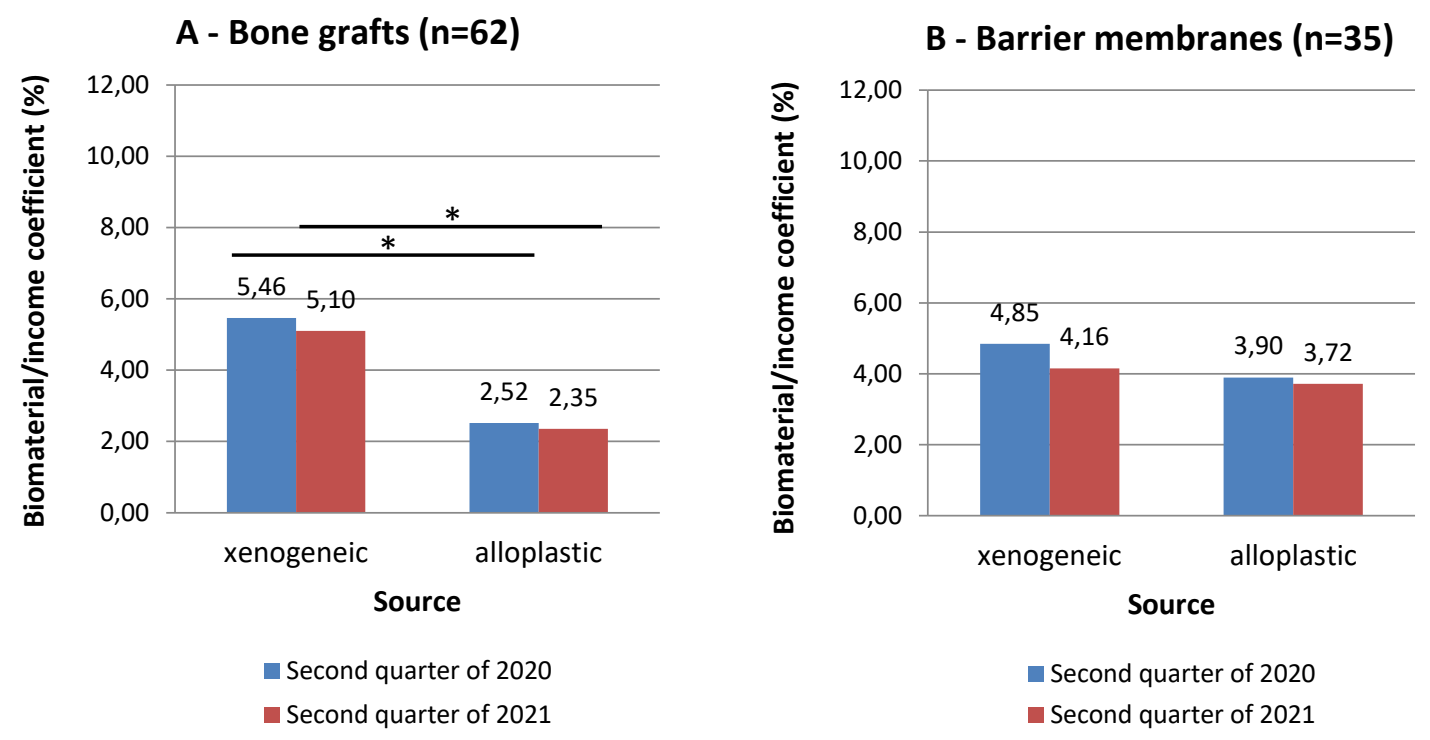

*P<0.05. Source: Elaborated by the authors (2021).

According to the industry, there was a high prevalence of Brazilian grafts (43 or $69.4 \%$ of this total) compared to foreign grafts (19 or $30.6 \%$ of this total), as well as among Brazilian membranes ( 24 or $68.6 \%$ of this total) and foreign membranes (11 or $31.4 \%$ of this total). The coefficient of imported biomaterials proved to be higher than that of the national ones, both for grafts and membranes, in the two periods analyzed. There was a small decrease in the biomaterial/income coefficient from the second quarter of 2020 to the second quarter of 2021 in all foreign products, while the coefficient of Brazilian biomaterials remained stable for membranes or had a slight increase for grafts, with statistical difference $(\mathrm{P}<0.05)$. Figure 3 illustrates the temporal analysis of biomaterial/income coefficient according to industry.

Figure 3 - Temporal analysis of biomaterial/income coefficient according to industry.
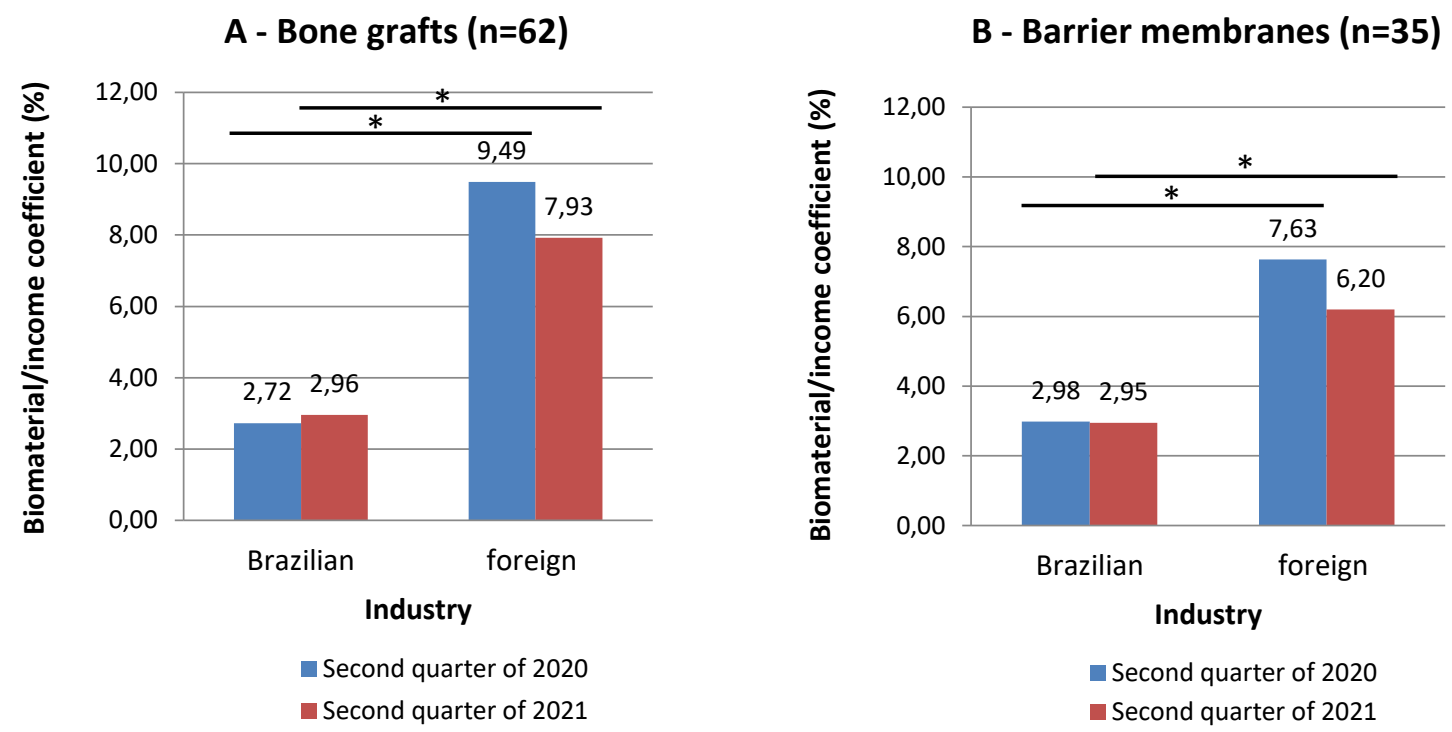

$* \mathrm{P}<0.05$. Source: Elaborated by the authors (2021). 
In an analysis by stratifications over the same period of time, all groups exhibited significant differences, except in the comparison between membranes of xenogeneic and alloplastic origin, both in the second quarter of $2020(\mathrm{p}=0.2626)$ and in the second quarter of 2021 ( $\mathrm{p}=0.2716)$.

In an overall analysis of the sample according to temporal variables, the biomaterial/income coefficient ranged from $0.77 \%$ to $22.78 \%$ (average of $4.67 \pm 4.40 \%$ ) in the second quarter of 2020 and from $0.79 \%$ to $20.38 \%$ (average of $4.30 \pm 3.96 \%$ ) in the second quarter of 2021. The high variability found could be explained according to different categories of marketed products. Wilcoxon test for comparing trends in consumption power showed a result of $\mathrm{V}=1630$, with a significant difference between the medians $(\mathrm{P}<0.001)$. An increase of 0.417 in the biomaterial/income coefficient was observed in relation to the second quarters of 2020 and 2021, which explains a trend towards homogeneity in the coefficient.

Figure 4 illustrates the analysis of the biomaterial/income coefficient for the dependent variables.

Figure 4 - Analysis of the biomaterial/income coefficient for the dependent variables.

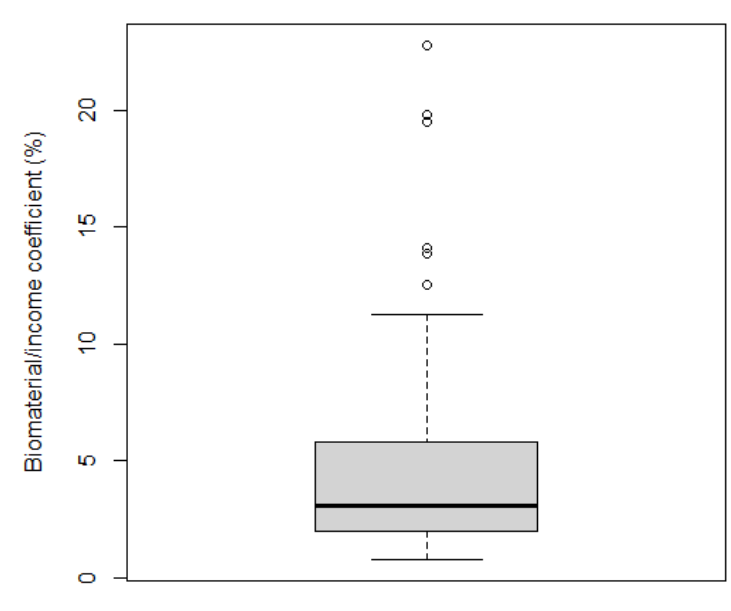

Second quarter of 2020

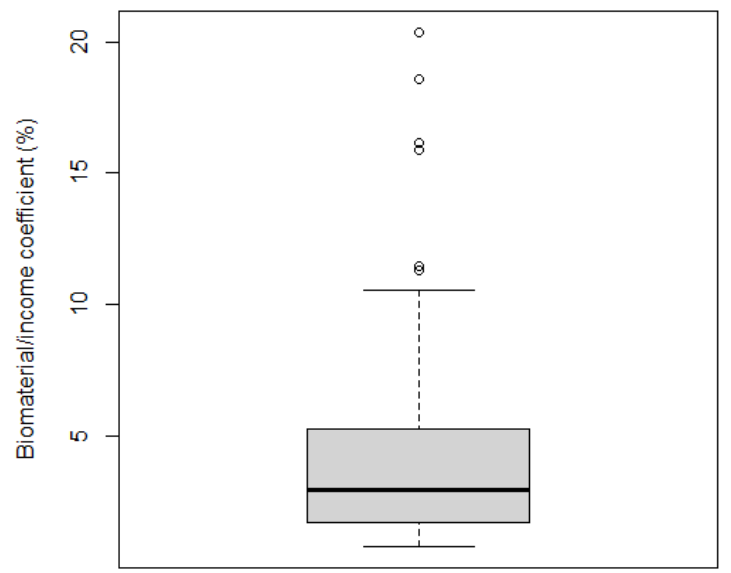

Second quarter of 2021

Source: Elaborated by the authors (2021).

\section{Discussion}

The results of this study converge with findings in the literature regarding the diversity of GBR biomaterials (Zion Market Research, 2021). Natural bioceramics such as demineralized bone matrix are still prevalent, although synthetic bone grafts segment, in particular represented by biphasic calcium phosphate ceramics, is expected to hold the largest market of dental bone graft substitutes for ridge augmentation and socket preservation during 2016-2026 (Maximize Market Research, 2021). Araújo et al. (2021) also found a higher prevalence of biopolymeric, xenogeneic and resorbable barrier membranes in the Brazilian dental market, being a set of products less explored than bone grafts.

The dental market in Brazil exhibited a marked preference for foreign products, in surveys prior to the pandemic (Araújo et al., 2020; Castro-Silva \& Coutinho, 2012). The greater availability of Brazilian products in this study, to the detriment of foreign products, could be explained by the higher import cost at the height of the pandemic in the second quarter of 2020, as well as logistical or supply problems during this period of blockage and economic instability, marked by deficit in the GDP, in investments and in the consumption of goods and services (Silva \& Silva, 2020). In this way, the foreign industry would have a greater impact on the consumer's purchasing power, making access to GBR biomaterials more limited in an already very cost-sensitive market (Araújo et al., 2020). 
The biomaterial/income coefficient was useful to estimate the economic value of these products for the consumer's budget. The use of socioeconomic indicators is useful to draw an overview of the Brazilian market, including human development index and GDP (Castro-Silva et al, 2021). According to Eaton et al. (2019), there are wide variations between EU Member States in the price of dental treatment and in terms of percentage of GDP per capita, the cost to the patient can range from $0.12 \%$ in France to $1.57 \%$ in Spain. Such indicators from developed countries, far below the estimates of the biomaterial/income coefficient, which have a much greater cost impact on Brazilian citizens' income, can reinforce the inequality in access to dental treatment faced in the country. In scenarios of scarcity, market assessments can be useful to help decision-making on clinical treatments, identifying the Brazilian consumer's purchasing power for dental materials and their access to specialized private services, which are rarely available in the public assistance network (Castro-Silva et al, 2013; Herkrath et al, 2020).

The world economic position of Brazil, 12th place in GDP per capita or 8th place in purchasing power parity (PPP) in USD, suggest the market potential of the country (Balassiano \& Considera, 2020). Nonetheless, the drop in economic activity in the Brazil and strong exchange rate devaluation in the period between 2011 and 2020 have been the causes of the so-called second lost decade of the last 40 years, with a stagnation due to an average real annual growth of $0.2 \%$ per year in GDP and an average retreat of $0.6 \%$ per year in GDP per capita (Balassiano \& Considera, 2020). The decline of GDP evidenced in the second quarter of 2020 also converges with the pandemic data and with the historical analysis of GDP present in the work of Solber (2020).

The slow improvement in the epidemiological situation after investment of $5.5 \%$ of Brazil's GDP in combating the pandemic coincided with the economic recovery observed in the second quarter of 2021, driven by an increase in aggregate savings from the lockdown period where consumption was very restricted (Silva \& Silva, 2020). This could explain the progressive general reduction in the biomaterial/income coefficient between the second quarters of 2020 and 2021 , supported by the improvement in the population's income in the analyzed time segments. However, the results of a drop in this coefficient for imported products clashes with the exchange rate variation, which remained more stable between the periods analyzed (IPEADATA, 2021).

Dentistry as a free market within a welfare state can be a persistent attempt to hold on to a compromise between the two very distinctive ideologies of the health professional and consumer (Franzon, 2018). Clear and adequate communication is essential to promote greater involvement between these actors to assess the risks, benefits, costs, prognoses and personal preferences that interfere with the dental service to be performed (Holden, 2018). Zaware (2020) highlights that better-known brands of dental materials can influence Indian dentists' preferences in clinical use. Outcome measures reported by dental patients offer great potential to drive improvements in oral health care (Listl, 2019). The joint therapeutic option between dentist and patient, weighing their financial availability and acceptance of the proposed biomaterial, seems to be the best decision making (Araújo et al., 2020; Castro-Silva \& Coutinho, 2012). Considering the ongoing course of the COVID-19 pandemic, the dental industry will work closely with the dental profession to adopt the necessary approaches, products, technologies and treatments to facilitate the resumption of wider dental activities (Proffitt, 2020).

Among the possible limitations of this study, a cross-sectional approach with analysis of only two quarters in different years can be highlighted. However, the second quarter of 2020 is clearly justified by revealing the darker face of the economic crisis associated with the COVID-19 pandemic (Alvarenga \& Silveira, 2021; Balassiano \& Considera, 2020) and the second quarter of 2021 a phase of beneficial recovery economic (Silva \& Silva, 2020). Despite this GDP recovery, Silber (2020) points out that Brazil has the fifth worst income distribution in the world, and it is recommended to consider the relationship of other variables to portray the post-pandemic economic situation, such as inflation and unemployment, which were not subject in this study. 


\section{Conclusion}

The present study discussed the economic impacts generated in the biomaterials market for guided bone regeneration, in Brazil, in a different pandemic periods. The reduction in the biomaterial/income coefficient was evident for bone grafts and barrier membranes, in their heterogeneous composition, sources and manufacturing industries. This indicates a greater purchasing power of biomaterials by the potential consumer. This work aids in the market research and consumer decision making, which is a little explored area when dealing with biomaterials. A suggestion for future studies would reside in the correlation of these data found with other social and economic indicators.

\section{Acknowledgments}

The authors would like to thank the Federal University of Ceara (Postgraduate Program in Biotechnology and Biomaterials Laboratory, Campus Sobral) which jointly enabled the realization of this research and the financial support of the Ceara State Foundation of Support for Scientific and Technological Development (CAPES/FUNCAP-AUXPE process n. $88881.166822 / 2018-01)$.

\section{References}

Aguilar, A., Twardowski, T., \& Wohlgemuth, R. (2019). Bioeconomy for Sustainable Development. Biotechnology Journal, 14 (8), e1800638. https://doi.org/10.1002/biot.201800638.

Alvarenga, D. \& Silveira, D. (2021). PIB do Brasil recua $0,1 \%$ no $2^{\circ}$ trimestre e recuperação perde fôlego. Portal de notícias G1. https://g1.globo.com/economia/noticia/2021/09/01/pib-do-brasil-recua-01percent-no-2o-trimestre.ghtml.

Araújo, L. K., Antunes, G. S., Melo, M. M., \& Castro-Silva, I. I. (2020). Brazilian dentists' perceptions of using bone grafts: an inland survey. Acta Odontologica Latinoamericana, 33 (3), 165-173. http://www.ncbi.nlm.nih.gov/pubmed/33523080.

Araújo, L. K., Cunha, A. L. A., Menezes, Y. A. T., Lopes, M. S., Maciel, J. A. C. \& Castro-Silva, I. I. (2021). Membranas osteopromotoras em Odontologia: tendências científicas e análise do mercado brasileiro. In: Fadel, C. B., Martins, A. S., Pinheiro, J. C. (Org.). Odontologia: pesquisa e práticas contemporâneas. 1. ed. São Paulo: Editora Científica Digital, 1, 103-120. https://doi.org/ 10.37885/210605075.

Balassiano, M. \& Considera, C. (2020). Posição relativa do PIB per capita do Brasil entre as maiores economias do mundo. Blog do ibre. https://blogdoibre.fgv.br/posts/posicao-relativa-do-pib-capita-do-brasil-entre-maiores-economias-do-mundo.

Cascaes, A. M., Camargo, M. B. J., Castilhos, E. D., Silva, A. E. R., \& Barros, A. J. D. (2018). Private dental insurance expenditure in Brazil. Revista de Saúde Pública, 52 (2018), e24. https://doi.org/10.11606/S1518-8787.2018052000340.

Cascaes, A. M., Dotto, L., \& Bomfim, R. A. (2018). Tendências da força de trabalho de cirurgiões-dentistas no Brasil, no período de 2007 a $2014:$ estudo de séries temporais com dados do Cadastro Nacional de Estabelecimentos de Saúde. Epidemiologia e Serviços de Saúde, 27 (1), e201723615. https://doi.org/10.5123/S1679-49742018000100015.

Castro, M. C., Massuda, A., Almeida, G., Menezes-Filho, N. A., Andrade, M. V., de Souza Noronha, K. V. M., Rocha, R., Macinko, J., Hone, T., Tasca, R., Giovanella, L., Malik, A. M., Werneck, H., Fachini, L. A. \& Atun, R. (2019). Brazil's unified health system: the first 30 years and prospects for the future. The Lancet, 394 (10195), 345-356. https://doi.org/10.1016/S0140-6736(19)31243-7.

Castro-Silva, I. I., Araújo, L. K., Souza, F. F. P. de, Ponte, J. S., Sousa, E. M. de, Jiménez, H. G. Q., Ferreira, F. V., Alcântara, L. G. de, Diniz, M. B. S., Menezes, Y. A. T., Azevedo, C. de H., Maciel, J. A. C. \& Melo, M. M. de. (2021). Pesquisa odontológica brasileira em regeneração óssea guiada: um estudo bibliométrico de quatro décadas. Research, Society and Development, 10 (2), e25510212504. https://doi.org/10.33448/rsd-v10i2.12504.

Castro-Silva, I. I. \& Coutinho, L. A. C. R. (2012). Uso de enxertos ósseos na Odontologia: perfil de cirurgiões-dentistas de Niterói/RJ. Revista Brasileira de Odontologia, 69 (2), 154-158. https://doi.org/10.18363/rbo.v69n2.p.154.

Castro-Silva, I. I., Ferreira, F. V., \& Maciel, J. A. C. (2021). Pesquisas em Biotecnologia no Brasil: Uma correlação espacial entre índice-H e desenvolvimento social. Research, Society and Development, 10 (1), e29910111807. https://doi.org/10.33448/rsd-v10i1.11807.

Castro-Silva, I. I., Lima, F. M. S. \& Granjeiro, J. M. (2013). Enxertos ósseos na odontologia brasileira: cenário, desafios e perspectivas na visão da gestão em saúde. Revista Fluminense de Odontologia. https://doi.org/10.22409/IJOSD.V1I39.213.

Costa, P. F. (2019). Translating Biofabrication to the Market. Trends in Biotechnology, 37 (10), 1032-1036. https://doi.org/10.1016/J.TIBTECH.2019.04.013.

Eaton, K. A., Ramsdale, M., Leggett, H., Csikar, J., Vinall, K., Whelton, H. \& Douglas, G. (2019). Variations in the provision and cost of oral healthcare in 11 European countries: a case study. International Dental Journal, 69 (2), 130-140. https://doi.org/10.1111/IDJ.12437.

Franzon, B., Englander, M., Axtelius, B. \& Klinge, B. (2018). Dentistry as a free market in the context of leading policymaking. International Journal of Qualitative Studies on Health and Well-Being, 13 (1), e1484218. https://doi.org/10.1080/17482631.2018.1484218. 
Haugen, H. J., Lyngstadaas, S. P., Rossi, F., \& Perale, G. (2019). Bone grafts: which is the ideal biomaterial? Journal of Clinical Periodontology, 46 (S21), 92-102. https://doi.org/10.1111/jcpe.13058.

Herkrath, F. J., Vettore, M. V. \& Werneck, G. L. (2020). Utilisation of dental services by Brazilian adults in rural and urban areas: a multi-group structural equation analysis using the Andersen behavioural model. BMC Public Health, 20 (1), e953. https://doi.org/10.1186/S12889-020-09100-X.

Holden, A. C. L. (2018). Consumer-driven and commercialised practice in dentistry: an ethical and professional problem? Medicine, Health Care and Philosophy, 21 (4), 583-589. https://doi.org/10.1007/S11019-018-9834-1.

IBGE (2021). Downloads - Estatísticas. Instituto Brasileiro de Geografia e Estatística. https://www.ibge.gov.br/estatisticas/downloads-estatisticas.html.

IPEADATA (2021). Instituto de Pesquisa Econômica Aplicada. https://www.ipeadata.gov.br.

Listl, S. (2019). Value-based oral health care: moving forward with dental patient-reported outcomes. Journal of Evidence Based Dental Practice, 19 (3), 255259. https://doi.org/10.1016/J.JEBDP.2019.101344.

Malta, M., Cardoso, L. O., Bastos, F. I., Magnanini, M. M. F. \& Silva, C. M. F. P. (2010). Iniciativa STROBE: subsídios para a comunicação de estudos observacionais. Revista de Saúde Pública, 44 (3): 559-565.

Matichescu, A., Ardelean, L. C., Rusu, L.-C., Craciun, D., Bratu, E. A., Babucea, M. \& Leretter, M. (2020). Advanced Biomaterials and Techniques for Oral Tissue Engineering and Regeneration-A Review. Materials, 13 (22), e5303. https://doi.org/10.3390/MA13225303.

Maximize Market Research (2021). Global Dental Bone Void Filler Market: Industry Analysis and Forecast. Maximize Market Research. https://www.maximizemarketresearch.com/market-report/global-dental-bone-void-filler-market/118748.

Montoya, C., Du, Y., Gianforcaro, A. L., Orrego, S., Yang, M. \& Lelkes, P. I. (2021). On the road to smart biomaterials for bone research: definitions, concepts, advances, and outlook. Bone Research, 9 (1), 1-16. https://doi.org/10.1038/s41413-020-00131-z.

Pereira, A. S., Shitsuka, D. M., Parreira, F. J. \& Shitsika, R. (2018). Metodologia da pesquisa científica. UFSM. https://repositorio.ufsm.br/bitstream/handle/1/15824/Lic_Computacao_Metodologia-Pesquisa-Cientifica.pdf?sequence=1.

Persistence Market Research (2021). Dental Biomaterial Market - Global Industry Analysis, Size, Share, Demand, Sales and Trends by 2026. https://www.persistencemarketresearch.com/market-research/dental-biomaterial-market.asp.

Proffitt, E. (2020). What will be the new normal for the dental industry? British Dental Journal, 228 (9), 678-680. https://doi.org/10.1038/s41415-020-1583-x.

Silber, S. D. (2020). A fragilidade econômica e financeira na pandemia do Sars-Covid-19. Estudos Avancados, 34 (100), 107-115. https://doi.org/10.1590/s0103-4014.2020.34100.008.

Silva, M. L. \& Silva, R. A. (2020). Economia brasileira pré, durante e pós-pandemia do covid-19: impactos e reflexões. Observatório socioeconômico da COVID-19. UFSM. https://www.ufsm.br/app/uploads/sites/820/2020/06/Textos-para-Discuss\%C3\%A3o-07-Economia-Brasileira-Pr\%C3\%A9-Durante-eP\%C3\%B3s-Pandemia.pdf.

Vujicic, M., Buchmueller, T. \& Klein, R. (2017). Dental care presents the highest level of financial barriers, compared to other types of health care services. Health Affairs, 35 (12), 2176-2182. https://doi.org/10.1377/HLTHAFF.2016.0800.

Yin, R. K. (2015). O estudo de caso. Planejamento e métodos. (5a ed). Bookman.

Zaware, P. D. N. (2020). Exploration of market potential towards dental material brands: an assessment with preferences of dentists in India. SSRN Electronic Journal, 24 (7), 4015-4026. https://doi.org/10.2139/SSRN.3819251.

Zion Market Research (2021). Brazil biomaterials market by product. Zion Market Research. https://www.zionmarketresearch.com/report/brazil-biomaterialsmarket. 